\title{
Status Hukum Sumber Daya Alam di Luar Jurisdiksi Nasional dan Posisi Negara Maju di Bidang Keantariksaan
}

\author{
Mardianis*
}

\begin{abstract}
Abstrak
Pengaturan kepemilikan dan penggunaan sumber daya alam di luar jurisdiksi nasional selalu menjadi perebutan dan perdebatan antara negara maju dan negara berkembang. Sampai saat ini sudah disahkan tiga rezim hukum internasional khusus yang berlaku untuk tiga wilayah sumber daya alam, yaitu Antartika, Laut Bebas khusus Dasar Laut Dalam, dan Antariksa khususnya Bulan. Ketiga rezim tersebut menggunakan konsepsi 'common heritage of mankind/warisan bersama umat manusia' sebagai prinsip utama pengaturannya. Tulisan ini dengan menggunakan metode penelitian normatif dan komparatif akan meneliti secara rinci variasi penerapan prinsip tersebut serta posisi negara maju di bidang keantariksaan terkait pemberlakuan rezim tersebut. Pada umumnya, konsep common heritage of mankind diterapkan dengan cara beragam dan sesuai dengan karakteristik sumber daya masing-masing sedangkan posisi negara maju di bidang kegiatan keantariksaan atau disebut juga space faring countries selalu mengkaitkan pemilikan dan penggunaan dengan kontribusi teknologi dan partisipasinya dalam memperoleh sumber daya tersebut.
\end{abstract}

Kata Kunci: yurisdiksi nasional, keantariksaan, negara maju, sumber daya alam, warisan bersama umat manusia.

\section{Legal Status of Natural Resources Beyond National Jurisdiction and the Position of the Developed Countries in Space Activities}

\begin{abstract}
The regulation on ownership and use of natural resources beyond national jurisdiction is always a struggle and a debate between the developed and developing countries. There are currently three special international legal regimes which apply to three areas, namely natural resources of Antarctica, the high seas particularly for seabed and subsoil, and outer space especially for the Moon. These three regimes use the conception of 'the common heritage of mankind' as the main principle of the regulations. This paper uses normative and comparative approaches to examine in detail the variation of application of this principle as well as the position of developed countries in the field of outer space related to the implementation of the regimes. In general, the common heritage of mankind concept is applied in a manner and in accordance with specific characteristic of its resources respectively while developed countries in space activities, also reffered to as space faring countries, are always associated with technological contribution and participation in obtaining these resources.
\end{abstract}

PADJADJARAN Jurnal IImu Hukum Volume 3 Nomor 3 Tahun 2016 [ISSN 2460-1543] [e-ISSN 2442-9325]

* Peneliti pada Pusat Kajian Kebijakan Penerbangan dan Antariksa, LAPAN, Jl. Cisadana No. 25 Cikini, Jakarta Pusat, mardianis65@yahoo.com, S.H. (Universitas Andalas), M.H., Dr. (Universitas Indonesia). 
Keywords: national jurisdiction, space activities, developed countries, natural resources, common heritage of mankind.

\section{A. Pendahuluan}

Dalam konteks hukum internasional dikenal 3 pemisahan wilayah yaitu wilayah kedaulatan, wilayah yurisdiksi, dan wilayah bebas/bersama. Untuk wilayah kedaulatan dan wilayah yurisdiksi dalam penggunaannya selalu dikaitkan dengan kata 'negara' tertentu sehingga sering disebut dengan 'kedaulatan negara' dan 'yurisdiksi negara'. Istilah kedaulatan negara sebagai salah satu prinsip tertua dalam hukum internasional berarti bahwa setiap negara memiliki yurisdiksi legislatif, yudikatif, dan eksekutif eksklusif atas kegiatan di wilayahnya. ${ }^{1}$ Sedangkan yurisdiksi dalam hukum internasional berarti hak dari negara untuk mengatur atau mempengaruhi oleh legislatif, eksekutif, atau yudisial atas hak-hak orang, properti, termasuk bertindak atau peristiwa sehubungan dengan hal-hal tersebut yang tidak secara eksklusif menjadi perhatian dalam negeri. ${ }^{2}$

Istilah yurisdiksi berasal dari dalam konsep wilayah yang aplikasinya muncul prinsip persamaan kedaulatan dan tidak intervensi pada urusan dalam negeri negara-negara. ${ }^{3}$ Doktrin yurisdiksi muncul pada abad ke-17 dari konsep kedaulatan dan teritorial. Perkembangan selanjutnya mengarah melalui the statue theory pada Huber-Storyan maxim dan menjadi tetap pada abad ke-19. Doktrin hukum internasional membedakan 4 (empat) kategori prinsip yang memberikan dasar hukum bagi yurisdiksi nasional, yakni: (1) wilayah sebagai dasar yurisdiksi (territory as a basis for jurisdiction); (2) kebangsaan sebagai dasar untuk yurisdiksi (nationality as a basis for jurisdiction); (3) prinsip perlindungan (the protective principle); dan (4) prinsip universalitas (the universality principle). Selanjutnya, konsep yurisdiksi negara dapat dibagi menjadi 3 (tiga) jenis, yaitu: teritorial, quasiteritorial, dan personal (territorial, quasi-territorial and personal). ${ }^{4}$

Sedangkan wilayah bebas dalam konteks hukum digunakan beberapa penyebutan, yaitu: (i) wilayah bersama (the global commons), (ii) wilayah di luar yurisdiksi nasional (beyond national jurisdiction), dan (iii) extra-territorial. Dua istilah awal dalam konteks hukum bermakna sama yaitu tidak adanya kepemilikan nasional terhadap wilayah tersebut, sedangkan extra-territorial dapat bermakna ganda yaitu sama seperti maksud kedua istilah terdahulu dan juga bisa dimaknai wilayah di luar wilayah nasional satu negara namun mungkin berada di wilayah

$1 \quad$ Kiss Alexandre dan Dinah Shelton, Guide to International Environmental Law, Boston: Martinus Nijhoff Publishers, 2007, hlm. 11-12.

2 Imre Anthony Csabafi, The Concept of State Jurisdiction in International Space Law: A Study in the Progressive Development of Space law in the United Nations, The Hague: Martinus Nijhoff, 1971, hlm. 49-50.

Ibid.

$4 \quad$ Ibid. 
negara lainnya. ${ }^{5}$ Dalam konteks pengaturan properti internasional (kepemilikan dan penggunaan), sampai saat ini masyarakat internasional baru mengenal 4 (empat) sumber utama, yaitu: (a) peraturan bersama global atau kepemilikan bersama (regulation of the global commons); (b) koordinasi lintas batas hak milik (coordination of transboundary property rights); (c) penerapan kebijakan global untuk melindungi terhadap bahaya tertentu (adoption of global policies to protect against specific harms); dan (d) perlindungan hak asasi manusia (protection of human rights). ${ }^{6}$

Tulisan ini akan meneliti pengaturan sumber daya alam di wilayah bebas atau wilayah di luar yurisdiksi nasional, yang dalam terminologi hukum dikenal dengan istilah global common (bersama global atau kepemilikan bersama), dengan titik fokus pada antariksa sebagai wilayah global. Sampai saat ini telah ditetapkan 3 (tiga) rezim hukum internasional khusus yang mengatur untuk 3 (tiga) wilayah bebas, yaitu: (i) Antartika, (ii) Laut Bebas khusus Dasar Laut Dalam, dan (iii) Antariksa khususnya Bulan. Sebagai suatu wilayah bersama atau global common, para pakar berpandangan bahwa padanya berlaku prinsip larangan pemilikan negara dan menyarankan bahwa sumber daya tersebut bukan milik siapapun. ${ }^{7}$ Dalam konteks ini, rezim pengaturan ketiga wilayah tersebut menetapkan konsep 'warisan bersama umat manusia' (common heritage of mankind-CHM) sebagai prinsip utama dalam pengaturannya. Menurut pandangan McDougall dan Cocca, sebagai suatu global commons ada 3 (tiga) kemungkinan status hukum pengaturannya, yaitu: ${ }^{8}$

1. res communis omnium, yaitu sumber daya alam bersama sebagai warisan bersama umat manusia diatur dan dicadangkan bagi semua bangsa;

2. res extra commercium, yaitu sumber daya alam bersama sebagai warisan bersama umat manusia diatur oleh sebuah organisasi internasional seperti Perserikatan Bangsa-Bangsa (PBB), dll; atau

3. res communis humanitatis, yaitu sumber daya alam bersama sebagai warisan bersama umat manusia tidak dimiliki oleh bangsa apapun tapi darinya semua bangsa dapat memperoleh keuntungan/manfaat.

Mengingat berbagai alternatif tersebut dan kepentingan negara-negara dalam tuntutan terhadap kepemilikan dan penggunaan sumber daya alam telah memunculkan perbedaan persepsi yang tajam antara negara maju keantariksaan dan negara berkembang. Negara maju keantariksaan diartikan sebagai negara yang

\footnotetext{
Contoh wilayah ekstra-territorial ini adalah kedutaan besar suatu negara di wilayah negara lainnya.

John G. Sprankling, "The Emergence of International Property Law", Pacific McGeorge School of Law Research Paper No. 11-06, University of the Pacific McGeorge School of Law, http://ssrn.com/abstract=1944214, hlm. 9.

7 Nicholas D. Welly, "Enlightened State-Interest-A Legal Framework For Protecting the "Common Interest of All Mankind" From Hardinian Tragedy", Journal of Space Law, Volume 36, 2010, hlm. 277-279.
}

$8 \quad$ Ibid. 
mampu dalam teknologi keantariksaan, utamanya dalam peluncuran satelit sendiri. Hal ini dilatarbelakangi asumsi bahwa negara yang mempunyai kemampuan tersebut secara otomatis memiliki kemampuan untuk mengklaim sumber daya alam dan melakukan ekplorasi terhadapnya dimanapun berada secara mandiri. Berdasarkan asumsi tersebut, menurut Pascale Ehrenfreund, negara ini adalah Republik Rakyat Tiongkok, Russia, Amerika Serikat, Jepang, India, Uni Eropa, Prancis, United Kingdom, Jerman, dan Italia. ${ }^{9}$ Sehubungan dengan hal tersebut, analisis status akan difokuskan pada keterlibatan negara-negara tersebut dalam ketiga rezim internasional dimaksud.

Penelitian ini merupakan penelitian terhadap 3 (tiga) pengaturan internasional tentang sumber daya di luar yurisdiksi nasional, yaitu: the 1959 Antarctic Treaty (Perjanjian Antartika 1959); United Nations Convention on the Law of the SeaUNCLOS 1982 (Konvensi Hukum Laut 1982), khususnya Perjanjian Laut Dalam dan Sumber daya didalamnya; dan Perjanjian Antariksa (the 1967 Treaty on the Principles Governing the Activities of States in the Exploration and Use of Outer Space, including the Moon and Other Celestial Bodies-Outer Space Treaty 1967) khususnya the 1979 Agreement Governing the Activities of States on the Moon and Other Celestial Bodies (Moon Treaty) dengan metode hukum normatif.

Penelitian hukum normatif tersendiri lebih menitikberatkan pada studi kepustakaan dengan menggunakan data sekunder. Beberapa literatur hukum akan digunakan sebagai sumber kepustakaan, terutama dalam mengkaji konsep dan teori. Sebagaimana diuraikan di atas, maka bagian pertama tulisan ini akan memuat kajian teoritis dan konseptual status hukum sumber daya dan pemanfaatannya di luar jurisdiksi nasional. Hal ini dimaksudkan untuk mengetahui hakekat dan permasalahan yang menjadi konsen negara-negara dalam pengaturan wilayah tersebut. Bagian kedua dalam pembahasan mencoba menjelaskan praktek pelaksanaan pengaturan ketiga wilayah dalam perjanjian internasional yang sudah disepakati dan staus negara tertentu yang telah menjadi pihak dari perjanjian tersebut. Selanjutnya akan dijelaskan perbandingan status hukum beberapa negara maju keantariksaan terhadap ketiga rezim perjanjian tersebut dan materi kunci perbedaan aturannya.

\section{B. Pembahasan}

\section{Definisi Sumber Daya Alam}

Terdapat banyak definisi sumber daya alam dalam literatur non-hukum, sebagai contoh bahwa sumber daya alam yang terjadi secara alami yang berguna bagi

9 Pascale Ehrenfreund, (et.al.), "Responsible Space Exploration and Use: Balancing Stakeholder Interests", New Space Journal, Space Policy Institute, Elliott School of International Affairs, George Washington University, 2013, hlm. 62. 
manusia atau dapat berguna berdasarkan teknologi, ekonomi atau keadaan sosial yang diperkirakan, atau 'pasokan yang diambil dari persediaan bumi seperti makanan, bangunan dan bahan pakaian, pupuk, logam, air dan tenaga panas bumi'. Berdasarkan hal tersebut maka untuk waktu yang lama, sumber daya alam adalah domain dari ilmu-ilmu alam. Sebagaimana seorang ekonom, yang dimuat dalam buku Nico Schrijver, Zimmerman menyatakan pada tahun 1933 sebagai berikut: ${ }^{10}$

"Selama berabad-abad sumber daya adalah anak tiri dari pemikiran ekonomi. Jika mereka diakui keseluruhan, mereka diserap ke dalam proses pasar, diakui hanya sejauh mereka dikurangi menjadi alat kerja pengusaha, tanah, tenaga kerja, dan modal, atau diakui melalui pengaruhnya terhadap biaya dan harga, pasokan dan permintaan."

Sampai saat ini, tidak ada definisi hukum yang berlaku umum untuk 'sumber daya alam' dalam hukum internasional. Dalam praktiknya, General Agreement on Tariffs and Trade (GATT) menggunakan istilah 'sumber daya alam terbatas' (exhaustible natural resources) (Pasal XX (g) dari GATT) ${ }^{11}$ yang dalam pengertian hanya berkaitan dengan sumber daya cadangan (seperti mineral) saja. Di samping itu, beberapa perjanjian memberikan definisinya sendiri untuk sumber daya alam tertentu. Misalnya Pasal 2 the 1958 Convention on the Continental Shelf (Konvensi Landas Kontinen 1958) yang diulang dalam Pasal 77 Konvensi Hukum Laut 1982 yang menyatakan bahwa: ${ }^{12}$

"Sumber daya alam ... terdiri dari mineral dan sumber daya non-hidup lainnya dari laut dan bawah tanah bersama-sama dengan organisme hidup milik spesies yang menetap, yang mengatakan, organisme yang, pada tahap dipanen, baik yang bergerak pada atau di bawah dasar laut atau tidak dapat bergerak kecuali dalam kontak fisik konstan dengan dasar laut atau lapisan tanah."

Selanjutnya dalam the 1968 African Convention on the Conservation of Nature and Natural Resources, istilah 'sumber daya alam' berarti 'sumber daya terbarukan', yaitu tanah, air, flora dan fauna. Sementara itu the 1992 Convention on Biological Diversity (CBD) menggunakan istilah 'sumber daya biologis' yang berarti 'sumber daya genetik, organisme atau bagiannya, populasi atau komponen biotik ekosistem-ekosistem lain dengan penggunaan aktual atau potensial atau nilai kemanusiaan'. Sejauh ini, upaya yang paling rinci tentang definisi sistematis dan klasifikasi sumber daya alam telah dibuat oleh ahli hukum Argentina, Cano, dalam

10 Nico Schrijver, Sovereignty over natural resources: Balancing rights and duties, Cambrdige: Cambridge University Press, 2008, hlm. 12-16.

11 General Agreement on Tariffs and Trade 1947 (GATT), 55 UNTS 187 (No. 814).

12 Convention on the Continental Shelf, done At Geneva, on 29 April 1958 (Convention on the Continental Shelf 1958). 
laporan Organisasi Pangan dan Pertanian (the Food and Agriculture OrganizationFAO). Cano menganjurkan untuk memperlakukan seluruh sumber daya alam kompleks sebagai suatu keseluruhan yang terintegrasi dan sebagai elemen konstitusional lingkungan manusia dan mendefinisikan sumber daya alam sebagai 'barang alam fisik, sebagai lawan yang dibuat oleh manusia' (yang disebut sumber daya budaya).

Sementara itu di tahun 1985, Rosenne mendekati masalah itu dari sudut yang sama, yaitu yang sumber daya yang tidak 'alami'. Dengan mengacu ke laut, ia menyebutkan bangkai kapal, pesawat cekung, benda arkeologi dan sejarah pulau buatan, serta platform minyak dapat ditambahkan. Selanjutnya, Trumpy berusaha untuk memperluas definisi Rosenne dan mengusulkan bahwa: "sumber daya adalah setiap berwujud atau tidak berwujud yang dapat digunakan secara ekonomi atau untuk menciptakan nilai ekonomi, dan yang bukan merupakan produk manufaktur atau peralatan". Berdasarkan hal di atas, tidak ada definisi yang memuaskan, karena hanya berorientasi ekonomi dan mengabaikan nilai intrinsik dari sumber daya alam dan integritas sistem ekologi, termasuk laut, udara, darat, dan flora dan faunanya. ${ }^{13}$

\section{Teori Pemanfaatan Sumber Daya Alam}

Sehubungan dengan hak kepemilikan dan kegunaan terhadap sumber daya alam di luar yurisdiksi nasional terdapat prinsip yang disebut dengan warisan bersama umat manusia (common heritage of mankinds-CHM). Prinsip CHM adalah konsep kontroversial yang muncul pada akhir tahun 1960-an untuk menantang konsep yang lebih tua yaitu res nullius dan res communis sebagai pendekatan hukum untuk mengatur penggunaan sumber daya bersama/umum (common resources). Berdasarkan prinsip res nullius, hewan liar serta tanaman yang sebagaimana dimasukkan ke dalam banyak sistem hukum tidak termasuk milik siapapun dan dapat digunakan secara bebas dan disesuaikan ketika diambil atau ditangkap. ${ }^{14}$ Sedangkan prinsip res communis menyiratkan sebaliknya, yang mana kepemilikan bersama akan menghalangi perampasan individu tetapi memungkinkan penggunaan sumber daya, misalnya untuk navigasi di laut lepas. ${ }^{15}$

Konsep CHM berbeda dari kedua konsep sebelumnya. Hal ini karena dimasukkannya kata 'warisan' yang menunjukkan aspek temporal dalam pengamanan komunal dari daerah hukum yang tidak dapat dimiliki nasional. Saat ini terdapat 3 (tiga) rezim hukum khusus yang mendasarkan pada konsep ini untuk mengatur pemanfaatan sumber daya, yaitu: Antartika (the 1959 Antarctic Treaty-

\footnotetext{
13 Nico Schrijver, Op.cit., hlm. 15.

14 Res nullius, which in many legal systems includes wild animals and plants, belongs to no one and can be freely used and appropriated when taken or captured.

15 Res communis, object which cannot be owned by anyone and which is subject to use by all.
} 
Perjanjian Antartika 1959), Dasar Laut dalam dan Tanah di bawahnya (the deep seabed and its subsoil), dan Bulan (Moon Treaty). Sifat warisan bersama adalah sebuah bentuk kepercayaan dengan tujuan utama berupa penggunaan eksklusif untuk tujuan damai, pemanfaatan rasional dalam semangat konservasi, manajemen yang baik atau penggunaan yang bijaksana, serta transmisi untuk generasi mendatang. Manfaat warisan bersama dapat dibagi dengan cara melalui alokasi yang adil dari pendapatan, tapi ini bukan fitur penting dari konsep ini, karena pembagian keuntungan juga bisa berarti berbagi pengetahuan ilmiah yang diperoleh di daerah warisan bersama dan hal ini diterapkan untuk pemanfaatan sumber daya di Antartika atau di Bulan.

Pada umumnya terdapat perbedaan pemberlakuan prinsip CHM terhadap ketiga wilayah hukum tersebut. Perbedaan ini dikarenakan adanya perbedaan tuntutan antara negara maju (dunia pertama) dan negara berkembang (dunia ketiga) terhadap pengaturan sumber daya alam itu. Perbedaan tuntutan tersebut terkait dengan hal-hal sebagai berikut: (i) Tuntutan dunia ketiga: pembagian yang adil dan akses ke sumber daya bersama terhadap argumen dunia pertama untuk penggunaan efisien yang dapat membatasi akses ke pengembang, tapi paling berkualitas yang pada akhirnya akan membawa manfaat yang lebih besar untuk semua orang; (ii) Dukungan dunia pertama: hak milik pribadi terhadap kebutuhan dunia ketiga berbasis argumen untuk pembagian yang adil dari barang dan jasa untuk memenuhi kebutuhan sosial populasi mereka; (iii) Tuntutan dunia ketiga untuk kedaulatan dan hak-hak privasi dalam kaitannya dengan akses dan transmisi informasi bisnis penting dan data sumber daya versus klaim hak dunia pertama untuk kebebasan informasi; dan (iv) Kepentingan dunia pertama untuk keamanan nasional dalam kaitannya dengan transfer teknologi dan penyalahgunaannya versus dunia ketiga: keinginan untuk otonomi yang lebih besar, baik secara teknis dan ekonomis, dengan hak partisipasi otonomi tersebut muncul dalam komunitas global. Perbedaan tuntutan tersebutlah yang menyebabkan terjadinya perbedaan penerapan dalam prinsip CHM sehingga kesepakatan diperoleh dengan mempertimbangkan kasus per kasus.

\section{Prinsip Common Heritage of Mankind}

Prinsip CHM, sebagaimana dipahami berawal dalam diskusi akademik pada tahun 1954 di Fifth International Congress yang diselenggarakan di University of Innsbruck dengan penyajian tulisan Die rechtliche Natur des Weltraums. Subjek ini kemudian dibawa ke forum akademis lainnya serta organisasi akademis internasional, dan menarik dukungan dari semua sistem hukum dan sosial. ${ }^{16}$

16 Aldo Armando Cocca, "Revaluation of the Concept of The Human Condition and The Common Heritage of Mankind: Keys to the Social Benefits of Space Technology", Acta Astronautica, Volume 19, Nomor 9, 1989, hlm. 781. 
Akhirnya, Aldo Armando Cocca berjuang untuk memasukkan prinsip ini ke dalam teks perjanjian internasional. Pada tanggal 19 Juni 1967, ia mengusulkan kepada PBB pada sidang pertama setelah pengesahan Outer Space Treaty 1967 oleh Majelis Umum. Sejak presentasinya diterima dengan baik oleh perwakilan pemerintah yang hadir, maka sebagai Kepala Delegasi Tetap Argentina pada Komite Penggunaan Antariksa Maksud Damai, beliau mempresentasikan sebuah rancangan perjanjian relatif untuk Bulan sebagai pelengkap alami Outer Space Treaty 1967 pada tanggal 3 Juli 1970. Rancangan tersebut berisi kalimat "warisan bersama umat manusia", yang mana untuk pertama kalinya menjadi dasar perjanjian antariksa.

Doktrin dan prinsip CHM telah diciptakan untuk memenuhi ambisi dan kebutuhan semua negara, baik negara maju maupun negara berkembang. Hanya karena kurangnya pengetahuan dan perspektif tentang masa depan umat manusia yang menyebabkan beberapa pemerintah menunda pelaksanaan prinsip berharga ini, yang berisi tidak hanya aspirasi para ahli hukum dan niat terbaik dan kehendak tegas dari negara anggota PBB ketika mereka menyetujui Moon Treaty dengan suara bulat di Majelis Umum pada tahun 1979, tetapi juga aspirasi para filsuf dan ilmuwan yang mengambil bagian dalam perundingan the United Nations Conference on the Exploration and Peaceful Uses of Outer Space II (UNISPACE 82). Semua ekspresi dan keinginan tercermin dalam upaya memenuhi respon mereka dalam prinsip hukum positif internasional yang dikenal sebagai the common heritage of mankind.

\section{Penerapan Prinsip CHM}

Secara umum, pengaturan internasional terkait dengan wilayah/ruang yang ditetapkan sebagai CHM terbatas hanya 3 (tiga) wilayah utama dan sumber daya padanya yaitu wilayah Antartika, dasar laut dalam, dan antariksa. Semua wilayah tersebut berada di luar yurisdiksi hukum dan politik dari individu anggota masyarakat internasional dan masing-masing terkait dengan perjanjian internasional yang berbeda dalam cara mereka menangani urusan penataan, akses, serta penggunaan sumber daya bersama untuk masing-masingnya.

Pada bagian ini akan mengungkap secara singkat fitur utama dan kerangka implementasi masing-masing dari perjanjian utama yang mengatur ketiga wilayah tersebut dan meneliti bagaimana perkembangannya dari waktu ke waktu dalam menanggapi perubahan ilmu pengetahuan dan teknologi dan isu-isu akses dan penggunaannya.

\section{a. Perjanjian Antartika 1959}

Lingkungan Antartika adalah salah satu wilayah yang paling terpencil, tak tersentuh, dan sebagian besar tak tersentuh oleh aktivitas manusia. Lingkungan ini mencakup area seluas 13.7 juta $\mathrm{km}^{2}$ yang ditutupi oleh lapisan es $4 \mathrm{~km}$ persegi dan 
ditumbuhi beragam flora dan fauna. Perjanjian Antartika 1959 ditetapkan untuk mengatur benua yang unik ini. Perjanjian ini merupakan tonggak penting dalam pembentukan kerangka hukum internasional untuk secara efektif mengatur dan mengelola lingkungan dan sumber daya untuk tujuan damai demi kepentingan umat manusia. ${ }^{17}$

Pengembangan Perjanjian Antartika 1959 diawali dari hasil penelitian ilmiah yang dilakukan selama Tahun Geofisika Internasional (IGY) tahun 1957-1958 dan perjanjian ini awalnya ditandatangani tahun 1959 oleh 12 negara. ${ }^{18}$ Saat ini Antartika telah diatur oleh serangkaian perjanjian: Perjanjian Antartika 1959, Protokol Lingkungan 1991 (the Environmental Protocol of 1991), Konvensi tentang Konservasi Sumber Daya Hidup di Laut Antartika 1980 (the Convention on the Conservation of Antarctic Marine Living Resources of 1980), dan Konvensi tentang Konservasi yang Mencakup Antartika 1972 (the Convention on the Conservation of Antarctic Seals of 1972).

Perjanjian Antartika 1959 merupakan salah satu instrumen yang paling penting dan inovatif dari hukum internasional. Perjanjian Antartika 1959 kini memiliki 45 negara pihak. Dua puluh delapan dari negara tersebut adalah pihak konsultatif yang menjadi penandatangan asli atau dengan melakukan penelitian besar. Negaranegara ini memiliki hak untuk berpartisipasi dalam pengambilan keputusan pada Pertemuan Pihak Konsultatif Antartika. Negara pihak pada perjanjian lainnya hanya diperbolehkan untuk menghadiri pertemuan tersebut. ${ }^{19}$

Perjanjian Antartika 1959 membagi anggotanya ke dalam 2 (dua) kategori: para pihak konsultatif dan para pihak non-konsultasi (consultative parties and nonconsultative parties). Para pihak konsultasi telah menunjukkan kepentingan di Antartika dengan melakukan kegiatan penelitian ilmiah yang substansial di sana. Berdasarkan Antarctic Treaty Systems (ATS), para pihak konsultatif juga merupakan orang-orang yang membuat keputusan mengikat tentang penggunaan Antartika. Sedangkan para pihak non-konsultasi adalah negara-negara yang telah mengaksesi perjanjian tetapi belum memenuhi uji kepentingan yang ditunjukan. Para pihak non-konsultasi tidak memiliki hak suara, tetapi mungkin mengamati pertemuan pengambilan keputusan. Sistem ini menjaga pengendalian Antartika berada pada negara-negara tersebut dengan benar dan kepentingan yang dipercaya.

ATS adalah unik karena menunda, tapi tidak meninggalkan, berbagai pernyataan klaim kedaulatan atas berbagai bagian dari Antartika. Memang banyak negara telah dan masih terus mengklaim bagian Antartika, tetapi masing-masing

17 Pascale Ehrenfreund, (et.al.), Op.cit., hlm. 61-63.

18 Penandatangan asli dari Perjanjian Antartika tahun 1959 adalah Argentina, Australia, Belgia, Chili, Perancis, Jepang, Selandia Baru, Norwegia, Afrika Selatan, Uni Soviet, Inggris, dan Amerika Serikat.

19 Fabio Tronchetti, The Exploitation of Natural Resources of the Moon and Other Celestial Bodies, Leiden-Boston: Martinus Nijhoff Publishers, 2009 hlm. 136-139. 
mengakui pembukaan Perjanjian Antartika 1959 yang menyatakan bahwa: "Antartika adalah untuk kepentingan seluruh umat manusia bahwa Antartika akan terus selamanya digunakan secara eksklusif untuk tujuan damai dan akan tidak menjadi ajang atau objek perselisihan internasional". ${ }^{20}$

Perjanjian Antartika 1959 terdiri dari pembukaan dan 14 Pasal. ${ }^{21}$ Perjanjian ini secara ringkas memuat ketentuan secara eksklusif penggunaan damai antartika bagi umat manusia; pembatasan yang ketat atas kegiatan militer dan pangkalan; tidak ada klaim berdaulat; tidak ada bahan peledak nuklir atau pembuangan limbah; dan penyelesaian damai isu-isu kontroversial. Sama pentingnya adalah fakta bahwa masyarakat internasional setuju untuk menunjuk benua ini sebagai dicadangkan untuk penyelidikan ilmu pengetahuan dan eksplorasi, dengan kerja sama berbagi informasi, kebebasan akses dan observasi, dan pertemuan konsultatif yang dibentuk, ketentuan amandemen, serta prosedur aksesi.

Berdasarkan perjanjian ini, yurisdiksi dan tanggung jawab untuk kegiatan nasional berada pada para pihak penandatangan perjanjian. Koordinasi penelitian ilmiah di Antartika ditugaskan pada Komite Ilmiah Penelitian Antartika (The Scientific Committee on Antarctic Research-SCAR) yang juga menyediakan saran ilmiah independen internasional untuk ATS dan badan-badan lainnya. ${ }^{22}$ SCAR adalah komite interdisipliner Dewan Internasional IImiah, yang pada gilirannya merupakan badan non-pemerintah yang terdiri dari himpunan anggota ilmiah nasional dan internasional. ${ }^{23}$

Perjanjian Antartika yang asli (bukan sebuah perjanjian PBB) telah dilengkapi selama puluhan tahun dengan sekitar 200 perjanjian dan tindakan-tindakan (secara kolektif disebut sebagai ATS yang telah dikembangkan dan disahkan melalui proses Rapat Permusyawaratan Perjanjian Antartika atau the Antarctic Treaty Consultative Meetings-ATCM). Dalam praktlknya, perjanjian memungkinkan fleksibelitas sistem tambahan yang dapat dilengkapi dengan langkah-langkah tambahan yang menjadi mengikat para pihak setelah penerimaannya, tanpa perlu mengubah perjanjian itu sendiri.

Selama bertahun-tahun, lampiran atas perjanjian melalui proses ATCM telah dibahas berbagai macam topik, seperti konservasi biota dan ekosistem, pengembangan protokol perlindungan lingkungan, pengelolaan limbah dan

20 Pascale Ehrenfreund, (et.al.), Op.cit., hlm. 62.

21 Perjanjian Antartika disahkan di Washington D.C., Amerika Serikat pada 1 Desember 1959. Dapat dilihat di http://www.ats.aq/documents/ats/treaty_original.pdf.

22 P.A. Berkman, (et.al.) (eds), Science Diplomacy: Antarctica, Science and the Goverance of International Spaces, Washington, DC: Smithsonian Institution Scholarly Press, 2011, hlm. 3.

23 SCAR is an interdisciplinary committee of the International Council for Science, which in turn is a nongovernmental body made up of national scientific members and international scientific unions. Dalam $\mathrm{H}$. Cohen, "Public participation in Antarctica: The role of nongovernmental and intergovernmental organizations" dalam buku Science Diplomacy: Antarctica, Science and the Governance of International Spaces yang disusun oleh P.A. Berkman, (et.al.) (eds), Op.cit., hlm. 271-276. 
langkah-langkah pengendalian pencemaran komprehensif, penunjukan kawasan khusus yang dikelola dan dilindungi, penilaian dampak lingkungan, dan moratorium kegiatan ekstraksi mineral. Ketentuan terakhir ini disahkan setelah penolakan Konvensi tentang Peraturan Kegiatan Sumber Daya Mineral Antartika 1988 (the 1988 Convention on the Regulation of Antarctic Mineral Resource Activities-CRAMRA), ${ }^{24}$ yang menunjukkan bahwa pertambangan untuk tujuan nonscientific tunduk pada pengendalian dan perpajakan oleh sebuah organisasi internasional. Pada Konferensi Perjanjian Antartika Madrid 1991, disetujui adanya moratorium 50 tahun eksplorasi dan pertambangan mineral yang berarti bahwa keputusan tentang pertambangan non-scientific masa depan di Antartika tidak akan ditinjau kembali sampai tahun 2041.

Penambahan, perubahan, dan modifikasi pada ATS hanya dapat dikerjakan oleh negara-negara yang memiliki kepentingan aktif di Antartika seperti yang ditunjukkan dengan melakukan kegiatan penelitian substansial di sana. Saat ini, ada 31 negara yang secara aktif melakukan program penelitian ilmiah di Antartika. Dengan demikian, keterlibatan kerja sama dalam modifikasi ATS juga merupakan insentif bagi negara-negara yang berpartisipasi dalam melakukan penelitian ilmiah di benua itu. Negara-negara yang tidak beroperasi di Antartika tidak memiliki hak untuk mengajukan perubahan perjanjian yang mengatur wilayah tersebut. ATS saat ini memiliki 49 negara penandatangan. Pengecualian untuk secara eksklusif kegiatan ilmiah di benua adalah pariwisata komersial. Pariwisata Antartika meliputi laut dan pariwisata udara, dan telah ada di Antartika terus sejak tahun 1966. Pariwisata Antartika ini dikelola oleh Asosiasi Internasional untuk Operasi Wisata Antartika (International Association of Antarctica Tour Operations), sebuah kelompok berbasis industri yang dikembangkan selama lebih dari 40 tahun.

\section{b. Konvensi PBB tentang Hukum Laut 1982}

Meskipun manusia telah menjelajahi dan menggunakan laut selama berabadabad, kemajuan teknologi di abad yang lalu telah menyoroti kebutuhan untuk perjanjian internasional yang menyeimbangkan kedaulatan territorial, penggunaan sumber daya, kebebasan laut lepas, dan gagasan pemerintahan bersama. Rezim hukum internasional atas lautan berakar pada UNCLOS III (mulai dibahas tahun 1973) yang berfokus pada isu-isu yang berkaitan dengan dasar laut dalam, pertambangan, sejauh mana laut teritorial, dan pelestarian lingkungan laut serta penelitian ilmiah. Penyusunan perjanjian memakan waktu 9 (sembilan) tahun, dengan dokumen final UNCLOS ditandatangani pada tahun 1982 dan mulai berlaku pada tahun 1994 (Konvensi Hukum Laut 1982). ${ }^{25}$

Saat ini, 163 negara telah meratifikasi Konvensi Hukum Laut 1982 yang

24 Convention on the Regulation of Antarctic Mineral Resource Activities 1988 (never in force).

25 United Nations Convention on the Law of the Sea (UNCLOS), adopted on 10 December 1982. 
merupakan kerangka kerja internasional yang mengatur penggunaan laut dan perjanjian yang paling banyak diratifikasi pada subjek ini. Dalam arti luas, Konvensi Hukum Laut 1982 memberikan alokasi yang jelas atas yurisdiksi dan batas-batas, prinsip-prinsip dasar perilaku, dan sistem penyelesaian sengketa wajib bagi negara dan masyarakat internasional. Melalui lebih dari 320 Pasal dan 9 Lampiran, Konvensi Hukum Laut 1982 menyediakan kerangka kerja global untuk hukum laut serta perjanjian tertentu tentang pengiriman, keselamatan, memancing, dumping di laut, dan perlindungan lingkungan. ${ }^{26}$

Konvensi Hukum Laut 1982 menetapkan laut sebagai CHM, mendefinisikan dan mengalokasikan wewenang atas zona maritim yang penting (misalnya laut teritorial, zona bersebelahan, zona ekonomi eksklusif, High Seas, batas kontinental, dan dasar laut yang dalam). Perjanjian itu membahas batas-batas laut teritorial, bagian atas dan bawah laut, navigasi dan transit internasional melalui berbagai zona, serta konservasi dan pengelolaan sumber kekayaan hayati. Konvensi Hukum Laut 1982 juga memasukan kode etik yang difokuskan pada perlindungan sumber daya yang digunakan untuk tujuan damai, tanggung jawab untuk kepatuhan, kerja sama dan bantuan teknis, dan tanggung jawab untuk kerusakan. Pada intinya, kontrol yurisdiksi bagian dari lautan dialokasikan oleh perjanjian untuk negaranegara pesisir. Negara pesisir ini dibutuhkan mengatur dengan cara yang menjamin integritas lingkungan dan pemanfaatan optimal sumber daya hidup lautan. Penandatangan juga diminta untuk menyelesaikan setiap perbedaan pendapat melalui pengadilan atau pengadilan yang dipilih.

Pelaksanaan perjanjian dicapai melalui penggunaan beberapa organisasi internasional yang berhubungan dengan pengaturan multilateral yang berbeda. Sebagai contoh, Organisasi Maritim Internasional (the International Maritime Organization) membahas masalah-masalah yang melibatkan kapal-kapal dan platform minyak lepas pantai, keselamatan dan polusi, serta pembuangan limbah di laut. Penawaran dengan konservasi perikanan FAO dan Program Lingkungan PBB memfasilitasi pertimbangan masalah lingkungan kelautan. Selain itu, terdapat pula program regional laut yang melibatkan sekitar 140 negara di seluruh dunia untuk masalah kelautan tertentu di berbagai bidang benua.

Pada tahun 1994, para perunding membuat modifikasi untuk 2 (dua) pasal kunci yang berkaitan dengan transfer teknologi wajib dan keterbatasan produksi dasar laut yang akhirnya dihapus dari perjanjian itu. Meskipun demikian, Konvensi Hukum Laut 1982 menyediakan kerangka kerja yang kuat untuk tata kelola dan manajemen laut serta isu-isu kompleks lainnya yang pasti akan memerlukan perhatian khusus untuk menjaga sumber daya yang sehat, produktif, dan dapat diakses laut dalam dekade mendatang.

Berdasarkan Konvensi Hukum Laut 1982, laut dalam dan dasar laut tidak

26 Pascale Ehrenfreund, (et.al.), Op.cit., hlm. 64-65. 
berada di bawah kedaulatan teritorial setiap negara, yang diklasifikasikan sebagai warisan bersama umat manusia. Daerah ini kaya akan deposit mineral, maka secara alami banyak negara dan swasta yang ingin menambang deposit ini. Berbeda dengan ATS, keanggotaan dalam Konvensi Hukum Laut 1982 tidak terbatas pada mereka yang terlibat dalam eksplorasi aktif, dan masing-masing anggota memberikan satu suara. Namun demikian, mirip dengan Moon Treaty, Konvensi Hukum Laut 1982 menyerukan pembentukan sebuah badan independen untuk mengatur eksploitasi, dan Otorita Dasar Laut Internasional (the International Seabed Authority-ISA) pun didirikan untuk mengatur operasi pertambangan pada tahun 1994. ISA mengatur eksploitasi laut dalam dengan mengharuskan penambang untuk membayar biaya sebesar $\$ 500.000$, bagian dari yang diberikan kepada negara-negara non-mining. ISA beroperasi di bawah 3 (tiga) fase, yaitu: ${ }^{27}$

(1) calon, atau pencarian non-eksklusif untuk mineral, yang dapat dilakukan secara gratis;

(2) eksplorasi, di mana negara atau entitas swasta dapat mengeksplorasi deposit mineral dengan eksklusivitas untuk \$250.000; dan

(3) eksploitasi, yang merupakan pemulihan komersial sebenarnya dari mineral untuk suatu biaya sebesar $\$ 250.000$.

Pelamar juga diharuskan untuk menyisihkan area dalam ukuran yang sama yang akan dicadangkan untuk pertambangan oleh badan pertambangan antar pemerintah ISA ini, dengan tujuan untuk bersaing dengan entitas swasta yang diberikan izin oleh ISA.

Untuk saat ini, pertambangan telah gagal untuk dikembangkan, mungkin karena efek dari rezim warisan bersama umat manusia ini dan biaya besar (\$500.000 dalam biaya ditambah cadangan wajib) terkait dengan pembangunan. Singkatnya, karena Konvensi Hukum Laut 1982 mensyaratkan transfer wajib teknologi, memberlakukan model ekonomi perusahaan pasar bebas, dan gagal menjamin akses ke sumber daya dalam dasar laut di masa depan, serta memasukkan struktur voting yang memberi semua bangsa kontrol yang sama terlepas dari kemampuan teknologi atau kontribusi mereka untuk eksplorasi bawah laut, Amerika Serikat dan negara-negara industri lainnya menolak untuk meratifikasi Konvensi Hukum Laut 1982.

\section{c. Perjanjian Antariksa dan Perjanjian Bulan}

\section{1) Perjanjian Antariksa}

Perjanjian tentang prinsip-prinsip yang mengatur kegiatan negara dalam Eksplorasi dan Pemanfaatan Antariksa termasuk Bulan dan Benda Langit lainnya (Treaty on Principles Governing the Activities of States in the Exploration and Use of Outer Space, Including the Moon and Other Celestial Bodies), lebih dikenal dengan Outer

27 Ibid., hlm. 65. 
Space Treaty 1967 terbuka untuk ditandatangani negara-negara sejak 27 Januari 1967 dan diberlakukan sebagai hukum positif (entry into force) sejak 10 Oktober 1967, dan dalam Undang-Undang Nomor 16 Tahun 2002 disebut sebagai Perjanjian Antariksa $1967 .{ }^{28}$ Sampai saat ini terdapat 103 negara yang telah meratifikasi Outer Space Treaty 1967 dan 25 negara penandatangan. ${ }^{29}$ Berdasarkan rumusan dari Pasal I dan II dari perjanjian ini, kalimat pertama Pasal I menyatakan: "eksplorasi dan penggunaan antariksa, termasuk bulan dan benda langit lainnya, harus dilakukan untuk kepentingan dan dalam kemanfaatan semua negara, terlepas dari tingkat ekonomi atau pengembangan ilmu pengetahuan mereka, dan akan menjadi provinsi seluruh umat manusia." Kata 'penggunaan' telah ditafsirkan sebagai 'eksploitasi' secara non eksklusif. ${ }^{30}$

Namun demikian, ada beberapa perdebatan efek klausul ini. Pada tahun 1967, ketika Kongres Amerika Serikat meratifikasi Outer Space Treaty 1967, Komite Senat Amerika Serikat untuk Hubungan Luar Negeri menyatakan bahwa:

"Tidak ada dalam Pasal I, ayat 1, mengurangi atau mengubah hak Amerika Serikat untuk menentukan bagaimana... Itu saham manfaat ... dan penggunaan kegiatan antariksa. Memang, beberapa telah menegaskan bahwa negara atau entitas swasta tidak akan diperlukan untuk melepaskan keuntungannya dari usaha antariksa."

Sementara itu James Trimble menulis:

"Manfaat yang diperoleh dari antariksa harus dibagi dengan semua umat manusia. Berbagi manfaat yang diharapkan tidak berarti berbagi keuntungan, melainkan dimaksudkan lebih sebagai pedoman filosofis. Cara di mana manfaat akan dibagi tergantung pada sifat dari manfaat dan kegiatan yang menghasilkan manfaat itu."

Ketidakpastian ini atas jenis dan jumlah keuntungan yang akan dibagikan adalah akar dari masalah anticommons. Penulis yang sama menyimpulkan, "perusahaan dapat melakukan usaha antariksa dengan harapan mempertahankan beberapa keuntungan untuk menghargai usaha mereka, tetapi sebagian dari hasil dan manfaat harus dibuat tersedia untuk masyarakat dunia."

Pasal II dari Perjanjian Antariksa menyatakan, secara keseluruhan: "Antariksa, termasuk bulan dan benda langit lainnya, tidak dikenakan perampasan nasional dengan klaim kedaulatan, dengan cara penggunaan atau pekerjaan, atau dengan cara lain."31 Ada perdebatan apakah bahasa 'anti-perampasan' ini berlaku untuk

28 Treaty on the Principles Governing the Activities of States in the Exploration and Use of Outer Space, including the Moon and Other Celestial Bodies, entered into force 10 October 1967 (Outer Space Treaty 1967).

29 Committee on the Peaceful Uses of Outer Space, "Report of the Legal Subcommittee on its fifty-fourth session", held in Vienna from 13 to 24 April 2015, A/AC.105/1090, 30 April 2015, hlm. 10.

30 Benjamin David Landry, "A Tragedy of The Anticommons: The Economic Inefficiencies of Space Law", Brook Journal International Law, Volume 38:2, 2013, hlm. 532-534. 
entitas publik dan swasta, dengan keseimpulan pandangan pakar yang bertentangan. Jadi bahkan jika badan swasta mampu mempertahankan sebagian besar keuntungan mereka melalui interpretasi Pasal I, itu tidak pasti apakah mereka dapat mengambil properti tanpa mengintai klaim kedaulatan untuk itu.

Rezim Outer Space Treaty 1967 masuk akal selama Perang Dingin, baik Amerika Serikat maupun Uni Soviet berusaha untuk memastikan bahwa tidak memperoleh keunggulan kompetitif dan mereka berhasil. Tapi rezim ini telah memiliki pengaruh menyesakkan pada ekonomi antariksa pasca-Perang Dingin secara internasional. Sebagai rekap, Outer Space Treaty 1967 bermasalah karena 2 (dua) alasan. Pertama, melarang negara dan badan swasta yang potensial, untuk melaksanakan kedaulatan (seperti pemilikan, menggunakan, atau memanfaatkan) atas antariksa (it prohibits states, and potentially private entities, from exercising sovereignty (e.g., appropriating, using, or exploiting) over outer space). Kedua, mensyaratkan jumlah yang kabur dari keuntungan yang akan dibagi antara semua negara (it requires a vague amount of the benefits to be shared between all states).

Bahkan jika pihak menafsirkan Outer Space Treaty 1967 secara menguntungkan-untuk memungkinkan perampasan pribadi properti dan untuk memungkinkan badan swasta untuk mempertahankan semua keuntungan mereka-ketidakpastian hukum semata-mata penafsiran ini tetap akan menghalangi investasi yang bermakna. Kombinasi masalah ini telah menciptakan sebuah lingkungan di mana usaha antariksa potensial menanggung semua biaya dan berdiri untuk kehilangan sebagian besar pengembalian.

\section{2) Perjanjian Bulan}

Perjanjian yang Mengatur Kegiatan Negara-negara Pada Bulan dan Benda Langit Lainnya (Agreement Governing the Activities of States on the Moon and Other Celestial Bodies), terbuka untuk ditandatangani negara-negara sejak 18 Desember 1979 dan berlaku sebagai hukum positif sejak 11 Juli $1984 .{ }^{32}$ Sampai saat ini baru 16 (enam belas) negara yang meratifikasi Moon Treaty dan 4 (empat) negara sebagai penandatangan. ${ }^{33}$ Karena itu, relevansi Moon Treaty ini dipertanyakan. Namun demikian, gambaran singkat akan menyoroti kekhawatiran negara maju keantariksaan dan menjelaskan mengapa Moon Treaty belum diratifikasi oleh negara tersebut.

Moon Treaty mengklasifikasikan antariksa sebagai warisan bersama umat manusia, mengandung klausul non-perampasan yang lebih inklusif, dan berisi persyaratan yang lebih langsung yang mana manfaat dibagi rata di antara semua negara (The Moon Treaty classifies outer space as the common heritage of

31 Article II Outer Space Treaty 1967.

32 Agreement Governing the Activities of States on the Moon and Other Celestial Bodies 1979 (Moon Treaty 1979).

33 Committee on the Peaceful Uses of Outer Space, Loc.cit. 
mankind, contains a more inclusive non-appropriation clause, and contains a more direct requirement that benefits be shared equally among all states). Pasal 11 ayat (3) menyatakan:

"Tidak satupun permukaan maupun bawah permukaan bulan [atau benda langit]... Akan menjadi milik setiap negara, organisasi internasional, antar-pemerintah atau non-pemerintah, organisasi nasional atau badan non-pemerintah atau setiap orang pribadi."

Oleh karena itu, berdasarkan Moon Treaty, bahkan tidak ada entitas swasta dapat memiliki properti di antariksa. Pasal 11 melanjutkan: "Negara Pihak Perjanjian ini dengan ini berjanji untuk mendirikan sebuah rezim internasional, termasuk prosedur yang tepat, untuk mengatur eksploitasi sumber daya alam Bulan sehingga eksploitasi tersebut akan menjadi layak." Perampasan properti karena itu dilarang, sambil menunggu pembentukan sebuah organisasi internasional untuk memfasilitasi itu. ${ }^{34}$

Negara maju keantariksaan membuat 2 (dua) argumen utama terhadap Moon Treaty. Pertama, negara-negara ini mengklaim bahwa penempatan kata dengan bahasa "moratorium eksploitasi komersial sumber daya sampai rezim internasional didirikan". Hal ini berarti bahwa tidak ada ekploitasi sumber daya alam di bulan sampai dibentuknya sebuah Otorita internasional yang mengaturnya. Namun sampai saat ini belum ada rezim otorita internasional tersebut yang dibentuk. Kedua, negara maju keantariksaan menyatakan bahwa setelah rezim didirikan, ia akan menjadi "tidak simpatik untuk usaha bebas" dan "karena manfaat harus dibagi rata di antara semua negara, terlepas dari kontribusi ekonomi mereka". Hal ini bermakna bahwa setelah rezim terbentuk, maka ekplorasi di Bulan tidak akan disetujui oleh negara maju yang melakukan ekplorasi karena hasilnya harus dibagi ke negara lain. Dengan cara ini, Moon Treaty melangkah lebih jauh daripada Outer Space Treaty 1967, tetapi karena itu, menyebabkan telah gagal untuk mendapatkan dukungan dari negara maju keantariksaan. ${ }^{35}$

Apabila kembali membahas mengenai antariksa, Outer Space Treaty selaku dasar hukum antariksa internasional mulai berlaku sebagai perjanjian PBB pada tahun 1967. Sebagaimana halnya dengan Perjanjian Antartika 1959, Outer Space Treaty juga merupakan perkembangan dari IGY dan kekhawatiran Perang Dingin

34 Article 11 of Moon Treaty 1979: "Neither the surface nor the subsurface of the moon [or any celestial body] ... shall become property of any state, international, inter-governmental or non-governmental organization, national organization or non-governmental entity or of any natural person." Therefore, under the Moon Treaty, not even private entities can appropriate property in outer space. Article 11 continues: "State Parties to this Agreement hereby undertake to establish an international regime, including appropriate procedures, to govern the exploitation of the natural resources of the Moon as such exploitation is about to become feasible." The appropriation of property is therefore outlawed, pending the establishment of an international organization to facilitate it).

35 Benjamin David Landry, Op.cit., hlm. 535. 
tentang pengaturan tata ruang internasional. Seratus negara telah meratifikasi perjanjian sampai saat ini, di antara mereka semua adalah kekuatan antariksa utama. Selain itu, 17 artikel dari Outer Space Treaty 1967 mengatasi masalah geopolitik penting sama seperti ATS.

Outer Space Treaty 1967 melarang menempatkan senjata nuklir atau senjata pemusnah massal di orbit Bumi atau pada benda angkasa lainnya, dan menetapkan bahwa eksplorasi dan penggunaan antariksa dilakukan secara bebas, damai, dan secara kolektif menguntungkan. Outer Space Treaty 1967 juga melarang klaim kedaulatan di antariksa dan pada setiap benda langit oleh negara manapun dan memberikan jurisdiksi dan tanggung jawab untuk kegiatan nasional (baik pemerintah maupun non-pemerintah) pihak yang menandatangani. Outer Space Treaty 1967 menegaskan bahwa antariksa merupakan 'provinsi seluruh umat manusia'36 dan menetapkan kebebasan akses, berbagi informasi secara terbuka pada ilmu pengetahuan dan kegiatan, dan konsultasi untuk menyelesaikan permasalahan/pertanyaan praktis.

Selain itu, pasal keprihatinan Outer Space Treaty 1967 tentang menghindari kontaminasi berbahaya dari benda langit dan perubahan yang merugikan ke Bumi. Meskipun tidak disebut sebagai sistem perjanjian, Outer Space Treaty 1967 juga telah menambahkan suksesi instrumen hukum lain dan perjanjian selama beberapa dekade yang berkaitan dengan penyelamatan dan kembalinya astronot; kewajiban untuk kerusakan oleh benda-benda antariksa; peluncuran kontrol yurisdiksi dan kepemilikan hardware; penggunaan orbit dan frekuensi; kegiatan di Bulan dan benda langit lainnya; penginderaan jauh Bumi; penggunaan sumber tenaga nuklir di antariksa; mitigasi sampah antariksa; dan kerja sama untuk kebutuhan pengembangan negara-negara.

Kerangka tata kelola untuk perjanjian adalah melalui Komite PBB tentang Penggunaan Damai Antariksa (COPUOS) dan Kantor PBB Urusan Antariksa. Committee on Space Research (COSPAR) yang didirikan pada tahun 1958 sebagai organisasi ilmiah independen non-pemerintah adalah lembaga pembuatan kebijakan internasional tentang perlindungan planet dan berfungsi sebagai badan konsultatif untuk COPUOS.

Mungkin salah satu perjanjian tambahan paling kontroversial untuk perjanjian asli adalah Moon Treaty yang berusaha untuk memperluas keberhasilan Outer Space Treaty 1967 dalam mengantisipasi meningkatnya aktivitas manusia di antariksa. Moon Treaty menegaskan bahwa Bulan dan sumber daya (yang tidak didefinisikan secara eksplisit) adalah 'warisan bersama umat manusia' dan

36 Article I Outer Space Treaty 1967: "The exploration and use of outer space, including the Moon and other celestial bodies, shall be carried out for the benefit and in the interests of all countries, irrespective of their degree of economic or scientific development, and shall be the province of all mankind." 
melarang eksploitasi sumber daya kecuali bila disetujui oleh sebuah organisasi internasional yang akan didirikan di masa depan. Moon Treaty telah diratifikasi oleh 13 negara, yang semuanya non-spacefaring. Perjanjian ini belum diratifikasi oleh kekuatan antariksa utama, termasuk Amerika Serikat, Rusia, Republik Rakyat Tiongkok, Jepang, dan berbagai negara Eropa. Meskipun secara teknis mulai berlaku pada tahun 1984, Moon Treaty tetap gagal de facto karena tidak adanya ratifikasi oleh semua kekuatan antariksa.

Kembali ke Bulan dalam waktu dekat akan cenderung cepat pembahasan tentang apa perjanjian yang diperlukan mengenai kegiatan manusia dan penggunaan sumber daya di luar orbit Bumi diperbaharui. Meskipun ada sejumlah perjanjian untuk komersialisasi dan penggunaan antariksa di Bumi rendah dan orbit geostasioner, saat ini ada tidak perjanjian yang diterima secara luas tentang eksploitasi komersial atau penggunaan sumber daya di Bulan, Mars, asteroid, atau benda langit lainnya. Selain itu tidak ada pula kerangka kerja manajemen lingkungan, sampah antariksa atau pedoman kontrol limbah atau kebijakan menghindari kontaminasi, kecuali mengenai perlindungan planet (yang telah diterapkan hanya untuk eksplorasi ilmu pengetahuan sampai saat ini).

\section{Status Negara Maju Dalam Rezim Sumber Daya di luar Jurisdiksi Nasional}

Dalam rangka menjelaskan posisi negara maju, khususnya negara maju keantariksaan yang dalam hal ini adalah Republik Rakyat Tiongkok, Russia, Amerika Serikat, Jepang, India, Uni Eropa, Prancis, United Kingdom, Jerman, dan Italia, maka perlu terlebih dahulu menguraikan tentang status keanggotaan negara tersebut pada perjanjian terkait wilayah dan sumber daya alam di atas. Berdasarkan data sampai saat ini, status negara-negara tersebut terhadap perjanjian yang diuraikan pada bagian B. 4 di atas adalah sebagaimana dimuat dalam tabel 5.1 berikut

Tabel 5.1. Legal Status of Each Treaty by Individual Space Powers: ${ }^{37}$

\begin{tabular}{|l|c|c|c|c|}
\hline & $\begin{array}{c}\text { Antarctic } \\
\text { Treaty }\end{array}$ & $\begin{array}{c}\text { Outer Space } \\
\text { Treaty }\end{array}$ & Moon Treaty & UNCLOS \\
\hline China (RRT) & $\mathrm{R}$ & $\mathrm{R}$ & $\mathrm{NR}$ & $\mathrm{R}$ \\
\hline Russia & $\mathrm{R}$ & $\mathrm{R}$ & $\mathrm{NR}$ & $\mathrm{R}$ \\
\hline United States & $\mathrm{R}$ & $\mathrm{R}$ & $\mathrm{NR}$ & $\begin{array}{c}\text { Signed, } \\
\text { Not Ratified }\end{array}$ \\
\hline Japan & $\mathrm{R}$ & $\mathrm{R}$ & $\mathrm{NR}$ & $\mathrm{R}$ \\
\hline India & $\mathrm{R}$ & $\mathrm{R}$ & $\begin{array}{c}\text { Signed, } \\
\text { Not Ratified }\end{array}$ & $\mathrm{R}$ \\
\hline
\end{tabular}

37 Pascale Ehrenfreund, (et.al.), Op.cit., hlm. 62. 


\begin{tabular}{|l|c|c|c|c|}
\hline & $\begin{array}{c}\text { Antarctic } \\
\text { Treaty }\end{array}$ & $\begin{array}{c}\text { Outer Space } \\
\text { Treaty }\end{array}$ & Moon Treaty & UNCLOS \\
\hline France & $\mathrm{R}$ & $\mathrm{R}$ & $\begin{array}{c}\text { Signed, } \\
\text { Not Ratified }\end{array}$ & $\mathrm{R}$ \\
\hline $\begin{array}{l}\text { United } \\
\text { Kingdom }\end{array}$ & $\mathrm{R}$ & $\mathrm{R}$ & $\mathrm{NR}$ & $\mathrm{R}$ \\
\hline Germany & $\mathrm{R}$ & $\mathrm{R}$ & $\mathrm{NR}$ & $\mathrm{R}$ \\
\hline Italy & $\mathrm{R}$ & $\mathrm{R}$ & $\mathrm{NR}$ & $\mathrm{R}$ \\
\hline
\end{tabular}

$R=$ Ratified, $N R=$ Not Ratified

Berdasarkan tabel tersebut terlihat bahwa pada Perjanjian Antartika 1959, Outer Space Treaty 1967, dan Konvensi Hukum Laut 1982, semua negara tersebut telah meratifikasi kecuali Amerika Serikat yang tidak meratifikasi Konvensi Hukum Laut 1982. Sedangkan terhadap Moon Treaty hampir semua tidak meratifikasi, hanya India dan Perancis yang telah berstatus negara penandatangan. Dari gambaran tersebut tercermin bahwa untuk sumber di Bumi (Antartika dan dasar laut dalam) pada umumnya negara-negara tersebut menyetujui pemberlakuan prinsip warisan bersama umat manusia. Sedangkan untuk kawasan di luar Bumi, masih memperdebatkan sungguhpun sudah ada aturan khusus untuk Bulan namun negara-negara tersebut tidak mau meratifikasi, sehingga dapat dinyatakan bahwa negara tersebut sebenarnya tidak menyetujui.

Selanjutnya berdasarkan materi muatan aturan ketiga pengaturan sumber daya alam tersebut, terlihat adanya persamaan dan perbedaan struktur dan elemen dalam cara menerapkan prinsip warisan bersama umat manusia tersebut. Untuk struktur dan elemen dimaksud dapat dilihat dalam tabel 5.2 dan 5.3 berikut:

Tabel 5.2.The Structure of Legal Regimes for Areas beyond National Sovereignty ${ }^{38}$

\begin{tabular}{|l|l|l|l|}
\hline \multicolumn{1}{|c|}{ Areas } & \multicolumn{1}{|c|}{$\begin{array}{c}\text { The Antarctica/ } \\
\text { On the Earth }\end{array}$} & \multicolumn{1}{c|}{$\begin{array}{l}\text { The Outer Space/ } \\
\text { Outside the Earth }\end{array}$} & $\begin{array}{l}\text { The High Sea of and Sea } \\
\text { bed/On the Earth }\end{array}$ \\
\hline $\begin{array}{l}\text { Special Legal } \\
\text { Regime }\end{array}$ & The Antarctic Treaty 1959 & $\begin{array}{l}\text { The Outer Space Treaty } \\
1967\end{array}$ & $\begin{array}{l}\text { The Law of the Seas } \\
\text { Convention 1982 }\end{array}$ \\
\hline Legal Status & $\begin{array}{l}\text { A quasi-sovereignty -free } \\
\text { area / "frozen" territorial } \\
\text { claims (art. IV) }\end{array}$ & $\begin{array}{l}\text { The Province of all } \\
\text { Mankind (art. I) }\end{array}$ & $\begin{array}{l}\text { The Common Heritage } \\
\text { of Mankind (arts. 89 } \\
\text { and 136) }\end{array}$ \\
\hline $\begin{array}{l}\text { The principles } \\
\text { \& experning the Use }\end{array}$ & $\begin{array}{l}\text { The peaceful purposes } \\
\text { (Art I) } \\
\text { Freedom of Scientific } \\
\text { investigation (article II) } \\
\text { International Cooperation } \\
\text { (Art III) }\end{array}$ & $\begin{array}{l}\text { Freedom of the outer } \\
\text { space (art I) } \\
\text { Non appropriation (art II) } \\
\text { International } \\
\text { Cooperation (Art I, III, X, } \\
\text { XI) } \\
\text { The peaceful purposes } \\
\text { (art IV) }\end{array}$ & $\begin{array}{l}\text { The Freedom of the } \\
\text { high Seas (Art 87) } \\
\text { The peaceful purposes } \\
\text { (art 88 \& 141) } \\
\text { International } \\
\text { Cooperation (Art 98, } \\
\text { 100, 150) }\end{array}$ \\
\hline
\end{tabular}

38 Chukeat Noichim, "International Cooperation For Sustainable Space Development", Journal of Space Law, Volume 31, 2005, hlm. 329. 
Table 5.3. Comparison of Key Provisions among the Four Treaties ${ }^{39}$

\begin{tabular}{|l|c|c|c|c|}
\hline & $\begin{array}{c}\text { Antarctic } \\
\text { Treaty }\end{array}$ & $\begin{array}{c}\text { Outer Space } \\
\text { Treaty }\end{array}$ & Moon Treaty & UNCLOS \\
\hline Peaceful Use & $\mathrm{Y}$ & $\mathrm{Y}$ & $\mathrm{Y}$ & $\mathrm{Y}$ \\
\hline Ban on military activity & $\mathrm{Y}$ & $\mathrm{Y}$ & $\mathrm{Y}$ & $\mathrm{N}$ \\
\hline Ban on claims on sovereignty & $\mathrm{Y}$ & $\mathrm{Y}$ & $\mathrm{Y}$ & $\mathrm{Y}$ \\
\hline Ban on nuclear weapons & $\mathrm{Y}$ & $\mathrm{Y}$ & $\mathrm{Y}$ & $\mathrm{N}$ \\
\hline Amendment procedure & $\mathrm{Y}$ & $\mathrm{N}$ & $\mathrm{Y}$ & $\mathrm{Y}$ \\
\hline $\begin{array}{l}\text { Use of phrase “common } \\
\text { heritage of mankind” }\end{array}$ & $\mathrm{N}$ & $\begin{array}{c}\text { Y-(“Province of all } \\
\text { mankind”) }\end{array}$ & $\mathrm{Y}$ & $\mathrm{Y}$ \\
\hline $\begin{array}{l}\text { Independent organiz. for } \\
\text { exploitation of resources }\end{array}$ & $\mathrm{N}$ & $\mathrm{N}$ & $\mathrm{Y}$ & $\mathrm{Y}$ \\
\hline Ban on private property & $\mathrm{N}$ & $\mathrm{N}$ & $\mathrm{Y}$ & $\mathrm{N}$ \\
\hline Exclusive Economic Zones & $\mathrm{N}$ & $\mathrm{N}$ & $\mathrm{N}$ & $\mathrm{Y}$ \\
\hline
\end{tabular}

Dari perbedaan dan persamaan elemen di atas, secara keseluruhan terdapat 9 (sembilan) elemen pengaturan atas sumber daya alam yang ditetapkan menerapkan prinsip CHM. Dapat dilihat bahwa 4 (empat) elemen diantaranya mencantumkan hal yang sama, yaitu: tujuan damai, larangan kegiatan militer, larangan tuntutan kedaulatan, dan pelarangan untuk tes senjata nuklir. Sedangkan 5 (lima) elemen lainnya memiliki perbedaan. Satu-satunya yang melarang kegiatan swasta untuk ekploitasi sumber daya dalam Moon Treaty. Namun karena negara yang mampu melakukan ekplorasi dan eksploitasi tidak satupun yang meratifikasi perjanjian tersebut, maka keberlakuan perjanjian ini masih perlu dipertanyakan.

\section{Penutup}

Berdasarkan uraian di atas dapat ditarik kesimpulan sebagai berikut:

1. Status hukum sumber daya alam di luar yurisdiksi nasional pada umumnya menerapkan Konsep CHM yang mendobrak pemberlakukan konsep zaman Romawi tradisional res nullius dan res communis yang dalam penerapannya ditemukan pada tiga rezim hukum khusus, yaitu: Antartika, Laut Bebas khususnya dasar laut dalam, dan antariksa khususnya Bulan, namun diaplikasikan dengan cara yang berbeda.

2. Keterlibatan negara-negara dalam 3 (tiga) rezim hukum khusus tersebut juga beragam sedangkan posisi negara maju keantariksaan pada umumnya menyetujui dan meratifikasi konsep CHM untuk wilayah di Bumi, namun berbeda untuk wilayah di luar bumi, khususnya Bulan.

3. Konsepsi pengaturan $\mathrm{CHM}$ terdapat sembila elemen pengaturan dan empat elemen diantaranya mencantumkan hal yang sama yaitu: tujuan damai, larangan kegiatan militer, larangan tuntutan kedaulatan dan pelarangan untuk tes senjata nuklir, sedangkan khusus kegiatan swasta dalam arti kegiatan 
kepentingan komersial, pada dasarnya prinsip CHM tidak melarang kegiatan swasta, namun hal ini terjadi dalam Moon Treaty.

4. Posisi negara maju di bidang kegiatan keantariksaan atau disebut juga space faring countries selalu mengkaitkan pemilikan dan penggunaan dengan kontribusi teknologi dan partisipasinya dalam memperoleh sumber daya tersebut.

\section{Daftar Pustaka}

\section{Buku}

Berkman, P.A., (et.al.) (eds), Science Diplomacy: Antarctica, Science and the Goverance of International Spaces, Smithsonian Institution Scholarly Press, Washington, DC, 2011

Csabafi, Imre Anthony, The Concept of State Jurisdiction in International Space Law:

A Study in the Progressive Development of Space law in the United Nations, Martinus Nijhoff, The Hague, 1971.

Kiss, Alexandre dan Dinah Shelton, Guide to International Environmental Law, Martinus Nijhoff Publishers, Boston, 2007.

Schrijver, Nico, Sovereignty over natural resources: Balancing rights and duties, Cambridge University Press, Cambrdige, 2008.

Tronchetti, Fabio, The Exploitation of Natural Resources of the Moon and Other Celestial Bodies, Martinus Nijhoff Publishers, Leiden-Boston, 2009.

\section{Dokumen Lain}

Cocca, Aldo Armando, "Revaluation of the Concept of The Human Condition and The Common Heritage of Mankind: Keys to the Social Benefits of Space Technology", Acta Astronautica, Volume 19, Nomor 9, 1989.

Committee on the Peaceful Uses of Outer Space, "Report of the Legal Subcommittee on its fifty-fourth session", held in Vienna from 13 to 24 April 2015, A/AC.105/1090, 30 April 2015.

Ehrenfreund, Pascale, (et.al.), "Responsible Space Exploration and Use: Balancing Stakeholder Interests", New Space Journal, Space Policy Institute, Elliott School of International Affairs, George Washington University, 2013.

Landry, Benjamin David, "A Tragedy of The Anticommons: The Economic Inefficiencies of Space Law", Brook Journal International Law, Volume 38:2, 2013.

Noichim, Chukeat, "International Cooperation For Sustainable Space Development", Journal of Space Law, Vol. 31, 2005.

Space Policy Institute, "Guide to Space Law Terms", George Washingthon University and Secure World Foundation (SWF), https://swfound.org/media/ 99172/guide_to_space_law_terms.pdf, 2012. 
Sprankling, John G., "The Emergence of International Property Law", Pacific McGeorge School of Law Research Paper No. 11-06, University of the Pacific McGeorge School of Law, http://ssrn.com/abstract=1944214.

Welly, Nicholas D., "Enlightened State-Interest-A Legal Framework For Protecting the "Common Interest of All Mankind" From Hardinian Tragedy", Journal of Space Law, Volume 36, 2010.

\section{Dokumen Hukum}

Antarctic Treaty 1959.

Agreement Governing the Activities of States on the Moon and Other Celestial Bodies 1979

Convention on The Continental Shelf, Done At Geneva, On 29 April 1958, Entry Into Force 10 June 1964.

General Agreement on Tariffs and Trade 1947, 55 UNTS 187(No. 814).

Treaty on the Principles Governing the Activities of States in the Exploration and Use

of Outer Space, including the Moon and Other Celestial Bodies, opened for signature 27 January 1967; entered into force 10 October 1967.

United Nations Convention on the Law of the Sea, adopted on 10 December 1982. 